\title{
Introgression Progress for Phenotypic Traits and Parent- progeny Diversity at Advanced Segregation Population From Oryza Barthii and Oryza Glaberrima/oryza Sativa Crosses
}

\section{Bosede Popoola}

University of Ibadan

Daniel Adewale ( $\nabla$ daniel.adewale@fuoye.edu.ng )

Federal University Oye-Ekiti

\section{Christopher Okonji}

Federal University Oye-Ekiti

Morufat Balogun

University of Ibadan

\section{Research Article}

Keywords: advanced population, gene introgression, inter-generation diversity, parent-progeny correlation, Oryza barthii, segregation

Posted Date: January 5th, 2022

DOI: https://doi.org/10.21203/rs.3.rs-1184168/v1

License: (c) (i) This work is licensed under a Creative Commons Attribution 4.0 International License. Read Full License 


\section{Abstract}

Rice is a cereal staple of global fame and importance. Oryza barthii, a wild species holds significant traits and its utilization in rice breeding is rare. This study traced introgression trend of heritable traits in the offspring of 0 . barthii with an Africa-Asian progenitor to $F_{8}$ and assessed diversity between the parents and the $F_{8}$ population. Significant $(\mathrm{P}<0.05)$ genotypic variation existed for all the traits except tiller number, panicle/meter squared, grains/panicle and 1000 grain weight. Grains/panicle and days to $50 \%$ flowering had respective least (3.34\%) and highest (96.32\%) broad sense heritabilities. All traits had lower GCV compared to PCV. The least (5.28\% and $8.05 \%)$ and the highest (90.8\% and $98.1 \%$ ) GCV and PCV were respectively from grains/panicle and tiller number. Clear variations on the panicles and grains include: variations in sizes, shapes, colours, presence or absence of awns. The total variance explained by five principal component axes was $80.1 \%$. Plant height at maturity was the only trait with significant ( $p$ $\leq 0.01$ ) correlation and regression between $F_{6}$ and $F_{7}$. Progenies resemblance to Parent 1(IRGC 104084) retrogressively declined but parent-offspring to parent 2 (TGS 25) progressively increased from $F_{6}$ to $F_{8}$. Three visible groups of rice type in this study were: the 0 . barthii $(11 \%)$, 0 . sativa $(67 \%)$ and the intermediate group (22\%). This research has added to rice genetic resources; an investigation of the nutritional status of the progenies would be an interesting research.

\section{Introduction}

Rice is a global staple which is cultivated on every continent except the Antarctica. It is adaptable to numerous climates, soil, altitudes, terrains etc. It is cultivated in more than 115 countries and feeds over $50 \%$ of the population in the world (Liu et al., 2015). Rice is a prince among cereals, producing the highest quantum of calories per unit of land (Gujja and Thiyagarajan, 2009) and it is the backbone of India's economy, providing direct employment to about 70 per cent working people (Vanniarajan and Ramalingam, 2011). It is dignified as relished culinary in different cultures and languages. It comes first among the important commercial food crops of the world (IRRI, 2005). Four hundred and eighty one million tonnes was the projected rice production for 2020 (Mohanty, 2009); attainment of this will be subject to the pandemic influence of COVID 19.

The cultivated rice, genus Oryza whose chromosome number is 12 (Matsuo et al., 1997) has over 20 species. Only two species, Africa rice - Oryza glaberrima (Steud.) and Asian rice - Oryza sativa (Linn.) are the cultivated species. 0. sativa originated from South-East Asia, particularly India and Indo-china, where its richest diversity exists (Li, 1970; Sampath, 1973). The species is well distributed throughout the tropics and parts of the temperate regions of the world (Oka, 1988). The primary and secondary centers of diversity for O. glaberrima is the swampy basin of the upper river Niger and the southwest near the Guinean coast (Maclean et al., 2002). The cultivation of 0 . glaberrima is confined to West Africa.

Crop wild relatives (CWR) harbours extremely valuable resources for crop breeding which through introgression can lead to considerable proportion of alleles sharing among rice cultivars (Jin et al., 2018). O. barthii is the progenitor of O. glaberrima (Linares, 2002; Sarla and Swamy 2005). It has long been recognized as a wild species of rice (Li et al., 2011) whose features (long flag leaf, presence of awns, long panicles, diverse grain sizes and weight) according AfricaRice (2012). A report (AfricaRice, 2012) hinted that the flag leaf shields the panicles from the sight of flying birds while the long awns could prevent insects from accessing the grains. Other very useful traits for which 0 . barthii is notable include: tolerance to drought, highly vigorous, high weed competitiveness, early maturing and production of many tillers (National Research Council, 1996). 
Crosses followed by selfing leads to the generation of segregating populations which allows gene expression for particular traits (Govintharaj et al., 2017). Parent offspring correlation and regression between two generations according to Vanniarajan and Ramalingam (2011) are usually undertaken to estimate the genetic proportion of gene transferred from one generation to other; it is noteworthy that parent-progeny correlation and regression are lesser influenced by the environment and it is a very useful method for selection in segregating population (Govintharaj et al., 2017). While available rice genetic resources needs to be sustainably conserved, continuous generation of variation remains a strong course of pursuit in plant breeding to enhance increased productivity and alleviate poverty and hunger. In the present study, our choice of the male and the female parent following Lin et al. (2020) was based on the identification of genetic variation between them.

The unique adaptive features in 0 . barthii may have enhanced its survival well over 3,500 years (AfricaRice, 2012). The same wild species holds significant features and wide diversity, yet it has been greatly underutilized in rice breeding programs. The present investigation seek to identify the possible introgression of heritable traits in the offspring of the wild species ( $O$. barthii) with and Africa-Asian rice and to access significant phenotypic diversity between the parents and the $F_{8}$ population. Moreover, the study seek to evaluate the level of diversity in the $8^{\text {th }}$ segregating populations derived from the cross.

\section{Materials And Methods}

Crosses were made between IRGC 104084 (Oryza barthii) and TGS 25 [(Oryza glaberrima x Oryza sativa) x Oryza sativa] to generate F1 hybrid. Through a three year selfing program involving seven cycles, 27 progenies were generated (See procedure in Figure 1). The 27 progenies and the two parents (See list in Table 1) were evaluated on the field. The experiment was laid out in an Augmented Randomized Complete Block Design at the Africa Rice regional station, International Institute of Tropical Agriculture (IITA), Ibadan (Latitude $7^{0} 30^{\prime} \mathrm{N}$ and Longitude $3^{0} 45^{\prime} \mathrm{E}$ ), Nigeria. Each of the test entries including the two parents were evaluated in single plots of 5 rows of 5 meter. The seeds were hand-dibbled at even depth and uniform spacing of $20 \times 20 \mathrm{~cm}$ apart. NPK 15-15-15 fertilizer was applied at the rate of $200 \mathrm{Kg} / \mathrm{ha}$ as basal application immediately after planting. Subsequently, $100 \mathrm{Kg} / \mathrm{ha}$ urea (46\% N) was applied in two equal split doses at tillering and panicle initiation stages. Weeding was carried out as at when due. The 27 progenies and the two parents were evaluated using Standard Evaluation system for Rice (SES, 2002) on the following traits: days to $50 \%$ flowering, days to $85 \%$ maturity, plant height at maturity, panicle length, fertility percentage, lodging score, shattering score, phenotypic acceptability, panicle exsertion, a thousand (1000) grain weight, number of panicles per plant, number of spikelets per panicle and grain yield per plot from which yield per hectare was estimated.

Analysis of variance (ANOVA) was carried out on the quantitative and transformed scored data following the procedure of Scott and Milliken (1993). A SAS program (version 9.4 (SAS, 2011) model Augmented Randomized Complete Block Designs was used. The linear model is as shown below:

$Y_{i j}=\mu+b_{j}+c_{i}+X_{i}\left(C_{i}\right)+\sum_{i j}$

Where: $Y_{i j}$ is the treatment, $\mu$ is the mean, $b_{j}$ denotes the block effect, $c i$ is the check effect and $X_{i}\left(C_{i}\right)$ denotes the entry effect.

Gower genetic distance was carried out using the $29 \times 15$ matrix mean values of genotypes and phenotypic traits. The obtained paired similarity distance was employed and subjected to principal component and clustering analysis. The parent progeny correlation and regression analysis between F6 with F7 and F7 with F8 was carried out following the 
procedure of Govintharaj et al. (2017) and Aananthi (2018). To further identify the introgressive trend for each genotype for the combined 15 phenotypic traits, similarity of each genotype to the two parents was performed for $F_{6}$, $\mathrm{F}_{7}$ and $\mathrm{F}_{8}$ data using Gower genetic distance in SAS (version 9.4 (SAS, 2011). Moreover, within the Statistical Tool for Agricultural Research (STAR, 2014) software, genotype by trait interaction was investigated and presented as a biplot graph.

\section{Results}

Table 2 presents descriptive and variance statistics and genetic estimates of 15 phenotypic data used in the evaluation of the two parents and $27 \mathrm{~F}_{8}$ progenies of IRGC 104084 x TGS 25 crosses. For the 29 genotypes, the means with the standard error and range of performances for the 15 traits for the 29 genotypes was presented in Table 2. Significant $(\mathrm{P}<0.05)$ genotypic variation existed for all the traits except tiller number, panicle/meter squared, grains/panicle and 1000 grain weight, moreover, tiller number had the least $(0.91) R^{2}$ and grains/panicle had the least (3.34\%) broad sense heritability (Table 2). Generally, the GCV were lower than the PCV, the least (5.28\% and 8.05\%) GCV and PCV were from grains/panicle while tiller number had the highest $(90.8 \%$ and $98.1 \%)$ for the two estimates (Table 2). The morphology of the ripe panicle of the two parents are presented in Plate 1. The panicle of 0 . barthii had awn and the panicle colour was black. The colour of the panicle of the 0 . sativa was straw (Plate 1). Phenotypic variability was observed on the panicles and the grains of the two parents and some of the progenies in Plate 2. Clear variations on the panicles and grains include: variations in sizes, shapes, colours, presence or absence of awns etc.; moreover, some of the progenies combined the features in the two parents in various proportion (Plate 2).

The five principal component axes in Table 3 had approximately 1.0 eigenvalues and above. The highest eigenvalues and correspondence variance proportion to the total variance was in PC1 and of the eigenvalues and contributions to total variance consistently decrease from PC1 to PC5 (Table 3). The total variance explained by the five PC axes was $80.1 \%$ (Table 3). Tiller number, panicle/meter square, panicle/plant, fertility percentage, panicle exsertion, lodging scoring, days to $50 \%$ flowering, days to $85 \%$ maturity and yield were prominent in their contribution to the variance proportion in PC1; panicle length, grain/panicle, shattering score, phenotypic acceptability and 1000 grain weight were prominent in PC2 while, plant height at maturity had the highest eigenvector loading in PC3 (Table 3). The eigenvector loadings of the mentioned variables (for each PC) were higher than 0.2 (Table 3). Six clusters were visible at 0.05 similarity coefficient and four clusters at 0.10 points of inflection (Figure 2). P1 stood alone in cluster I, cluster III (with only two genotypes) was closest to it with Gower genetic similarity of 0.95(Table not shown) and both clusters joined at 0.125 similarity point (Figure 2). Cluster II had the highest (20) population of genotypes. Within cluster II (which had P2 as one of its member), two sub-clusters with a population of 11 and nine were prominent (Figure 2). The similarities within each of the two sub clusters were 0.79 (one with 11 genotypes) and 0.80 (one with nine genotypes), but similarity within cluster II was 0.78 (Table not shown). Cluster IV contained six genotypes, it was more an independent population, an intermediate between 0 . barthii and 0 . sativa. It was the last cluster to merge with the others at an inflection point beyond 0.2 (Figure 2). The Gower genetic similarities of the six genotypes was 0.79 (Table not shown).

Mean performances of the different groups of genotypes in the various clusters is presented in Table 4. P1 (IRGC 104084) which solely occupied cluster I had the least value for plant height at maturity, panicle length, grain/panicle and yield. However, the same genotype highest value for tiller number, shattering score, phenotypic acceptability, panicle exsertion and 1000 grain weight (Table 4). The twenty genotypes in cluster II had the least 1000 grain weight but the second best final grain yield. G3 and G21 which were the only two members of cluster III had the highest mean for: plant height, PAM, panicle length, panicles/plant, fertility percentage, grains/panicle, lodging score and the 
highest yield, the genotypes in the cluster had the lowest value for: shattering score, PA, PE, days to $50 \%$ flowering and days to $85 \%$ maturity (Table 4 ). Cluster IV was distinguished for the lowest tiller number, PAM, panicle length, fertility $\%$ and zero lodging but flowered and matured latest (Table 4).

The total variance which captured the display of genotype by trait interaction in Figure 3 by the first two PC axes was $52.3 \%$. The interactions featured in the four quadrants. Parent 1 and 2 were separately located at quadrants one and three respectively (Figure 3). Panicle exsertion, phenotypic acceptability and shattering scores were the prominent traits in the first quadrant, P1, G1, G12 and G14 were the genotypes with corresponding highest values for them (Figure 3). In quadrant two, G3, G9, G20, G21, G22, G25, G26 and G27 had significant higher performances for: 1000 grain weight, logging score, tiller number, panicle length and panicle/metre square(Figure 3). Prominent traits associating with the nine genotypes in quadrant three were: fertility \%, height at maturity, panicle length, grains/panicle and yield. Days to $50 \%$ flowering and days to $85 \%$ maturity were significantly correlated in quadrant four and genotypes with significant association with them include: G11, G12, G13, G15, G16, G17 and G23 (Figure 3).

Quantitative similarities/resemblance of the 27 progenies to the two parents was through Gower genetic distance was presented in Table 5. Generally, similarity of the 27 progenies to P1 declined linearly from F6 to F8 while the similarity of the same 27 progenies to the P2 rose from F6 to F8 in a positive linear trend (Table 5). Individual similarity of the 27 progenies to the two parents differed and four notable trend responses were identified which include: positive linear, negative linear, positive quadratic and negative quadratic. With P1, 40.8\% of the progenies exhibited negative linearity, $37 \%$ exhibited positive quadratic and $22.2 \%$ exhibited negative quadratic trend response from F6 to F8 (Table 5). Furthermore in Table 5 with P2, the respective percentage response of the similarity of the 27 progenies were: $14.8 \%$ (positive linear), $14.8 \%$ (negative linear), $40.8 \%$ (positive quadratic) and $29.6 \%$ (negative quadratic). Among the eight phenotypic traits measured for the three generations $\left(F_{6}, F_{7}\right.$ and $\left.F_{8}\right)$ in Table 6 , only plant height at maturity had significant $(p \leq 0.01)$ correlation and regression between $F_{6}$ and $F_{7}$.

\section{Discussion}

Continuous selfing of the earlier generation of progeny to advanced generations is aimed at obtaining higher homozygotic status in the progenies. The main objective of single seed descent method is to rapidly advance the generation of crosses and at the end a random sample of homozygous genotype is obtained (Agriinfo, 2011; Kanbar et al., 2011; Janwan et al., 2013). Oryza barthii derivatives are useful sources of positive alleles especially for one thousand grain weight, high number of grains per panicle, high tillering ability, early flowering and high milling yield (Maricel, 2010).

The gross similarity of the 27 progenies to the two parents at $F_{6}, F_{7}$ and $F_{8}$ were at opposite linear trend: progenies resemblance to $P 1$ declined but increased to $P 2$ from $F_{6}$ to $F_{8}$. Therefore with P1 (IRGC 104084) cytoplasmic inheritance (Falconer and Mackay 1996; Wolf and Wade, 2009) played very little or no role in the diversity observed within the population of IRGC 104084 and TGS 25 cross. With reference to all the considered phenotypic traits, the range of resemblance of the 27 progenies with P1 (IRGC 104084) was $45.5-66.1 \%$, while the range of similarities of the same 27 progenies with P2 (TGS 25) was 58.7 - 83.7\%. Based on plant types, three groups were visible in this study, they are: the 0 . barthii group (11\%), O. sativa group (67\%) and the intermediate plant type group (22\%). This informs that the research process has led to the increase of genetic diversity in rice germplasm thus providing more genetic resources with promising potentials for rice improvement programme. Moreover, the origination of a new group (the intermediate) stemmed from the hybridization programme of crop alleles into crop wild relative (CWR) species/populations, according to Jin et al. (2018) the introgression procedure has changed the genetic structure of the progenies and thus increased diversity within the genus Oryza. Continuous creation of variation is a primary duty 
in plant breeding because abundance of genetic diversity and rational population structure of germplasm benefit crop breeding greatly (Liu et al., 2015).

Genotypes with lower score for phenotypic acceptability and panicle exsertion tend to be tall plants. Hence these two traits could be used to guide selection for shorter plants with less likelihood for lodging. Number of tillers per plant, panicle length and number of grains per panicle were positively correlated indicating that these traits are good selection indices for grain yield. These results were in agreement with the findings of Prasad et al (2001) and Sürek 1988. High fertility was associated with high number of grains per panicle, high grain yield and high one thousand grain weight. This is also in agreement with the findings of Prasad et al (2001). The panicle exsertion having a negative correlation with number of grains per panicle and grain yield shows that genotypes with lower scores for panicle exsertion (well exserted panicles) also yield better. Lower phenotypic acceptability score, lower panicle exsertion score and lower lodging percentage also indicate higher yield. Rice genotypes with a higher number of tillers per plant, high panicles per meter square and panicle length were observed to have higher yields. This is in agreement with the findings of Prasad et al (2001). These traits could therefore be used as selection indices for higher yield. Higher fertility, higher number of grains per panicle, lower phenotypic acceptability score and lower panicle exsertion score also positively influenced number of grains per panicle, grain yield and one thousand grain weight and could also be used to select for higher yielding genotypes. Heritability is a very important genetic estimate (Yadav et al., 2007 and Prajapati et al., 2011) with immense utility in trait-based genotype selection. High heritability estimate was observed in plant height at maturity, fertility percent, panicle length, shattering score, phenotypic acceptability, panicle exsertion, days to $50 \%$ flowering and days to $85 \%$ maturity; this corroborates the findings of Ogunbayo et al. (2014). High heritability indicates that the traits are more influenced by genetic contribution.

$F_{6}-F_{7}$ and $F_{7}-F_{8}$ seemed to be too advanced a stage for effective selection of majority of the measured phenotypic traits in this study except plant height at maturity. Selection response of traits differ among traits and the most effective generation to make selection for each trait based on correlation and regression analyses outcome equally differs. In respect of segregation generations, many authors (Vanniarajan and Ramalingam, 2011; Govintharaj et al., 2017; Aananthi, 2018) have hinted that selection at earlier generations are most effective for many traits. Majority $(88 \%)$ of our measured traits may be conforming to the above since our single plant selection program commenced at $F_{6}$. However, there are some traits whose effective selection would be most appropriate at the advanced generations (Kahani and Hittalmani, 2016; Aananthi, 2018). Our study identify plant height at maturity as one of such phenotypic traits whose most effective selection can be achieved at $F_{6}-F_{7}$ intergeneration and indicating $F_{6}$ as a good indicator for $F_{7}$ performances. Selection of traits and identification of superior genotypes is most reliably effective at the generation when the correlation and regression analyses are both significant.

\section{Declarations}

\section{Acknowledgement}

The authors would like to appreciate Africa Rice Center for supporting the execution of this research. Late Dr. C.O. Ilori was actively involved in this research. He became demised before the preparation pf this publication. His role is greatly appreciated. May His soul rest in peace.

\section{Author contributions}

PBO, COI and ABD - Conceptualization; PBO - Data curation; ABD and PBO - Formal analysis; PBO, ABD, OCJ and BMO

- Investigation; PBO, COI and ABD - Methodology; PBO - Resources; COI, ABD and BMO - Supervision; PBO - original 
draft; ABD, CJO and BMO - review and editing.

\section{Competing Interests}

The authors did not declare any conflict of interest

\section{Funding}

NONE

\section{Data Availability}

Data are available on reasonable request from the corresponding author.

\section{Ethics Approval}

\section{Research involving Human Participants and/or Animals}

None

Informed consent

None

\section{References}

1. Aananthi N (2018) Inter Generation Trait Association and Regression Analysis in F2 and F3 Generations of Rice. Int J Curr Microbiol Appl Sci 7: 3651-3662. https://doi.org/10.20546/ijcmas.2018.708.370.

2. Africa Rice Center (AfricaRice) (2012) A new rice research for development strategy for Africa. Africa Rice Center Annual Report 2011 Cotonou, Benin.

3. Falconer DS, Mackay TFC (1996) Introduction to Quantitative Genetics. Longman Scientific \&Technical Ltd, Essex.

4. Govintharaj P, Tannidi S, Swaminathan M, Sabariappan R (2017) Effectiveness of selection, parent-offspring correlation and regression in bacterial blight resistance genes introgressed rice segregating population. Ciência Rural, Santa Maria. 47: 09 - 14. http://dx.doi.org/10.1590/0103-8478cr20160987.

5. Gujja B, Thiyagarajan TM (2009) New hope for Indian food security? The system of rice Intensification. The Gatekeeper Series. 143: 1 - 18.

6. Ikeda R (2004) For the development of sustainable rice cultivation in Africa. JIRCAS. Newsletter 38: 22 - 28.

7. IRRI (2005) Research Paper Series. IRRI. Los Baños, Philippines.

8. Janwan M, Sreewongchai T, Sripichitt P (2013) Rice Breeding for High Yield by Advanced Single Seed Descent Method of Selection. J Plant Sci 8: 24-30. doi:10.3923/jps.2013.24.30.

9. Jin X, Chen Y, Liu P, Li C, Cai XX, Rong J, Lu BR (2018) Introgression from cultivated rice alters genetic structures of wild relative populations: implications for in situ conservation. AoB Plants. 10: plx055; doi:

10.1093/aobpla/plx055.

10. Kahani F, Hittalmani S (2016) Identification of F2 and F3 segregants of fifteen rice crosses suitable for cultivation under aerobic situation. Sabrao J Breed Gen. 48: 219 - 229.

11. Kanbar A, Kondo K, Shashidhar HE (2011) Comparative efficiency of pedigree, modified bulk and single seed descent breeding methods of selection for developing high-yielding lines in rice (Oryza sativa L.) under aerobic condition. Electr J Plant Breed 2:184-193. 
12. Khush GS (1997) Origin, dispersal, cultivation and variation of rice. Plant Mol Bio 35:25-34.

13. Lin Z, Qin P, Zhang X, Fu C, Deng H, Fu X, Huang Z, Jiang S, Li C, Tang X, Wang X, He G, Yang Y, He H, Deng XW (2020) Divergent selection and genetic introgression shape the genome landscape of heterosis in hybrid rice. Proc Nat Acad Sci 117: 4623-4631. doi/10.1073/pnas.1919086117

14. Li KS (1970). The origin of cultivated plants in Southeast Asia. Eco Bot. 24:3-19. https://doi.org/10.1007/BF02860628

15. Liu D, Wang J, Wang X, Yang XJ, Sun J, Chen W (2015) Genetic diversity and elite gene introgression reveal the japonica rice breeding in northern China. J Integ Agric 14: 811-822. https://doi.org/10.1016/S20953119(15)61050-4

16. Li ZM, Zheng XM, Ge S (2011) Genetic diversity and domestication history of African rice (Oryza glaberrima) as inferred from multiple gene sequences. Theor Appl Genet 123:21-31. Https://doi.org/10.1007/s00122-011-1563-2

17. Linares OF (2002) African rice (Oryza glaberrima); history and future potential.Proceedings of the National Academy of Sciences of the United States of America. 99 :1636016365. https://doi.org/10.1073/pnas.252604599.

18. MacLean JL, Dawe DC, Hardy B, Hettel GP (2002) Rice Almanac. Los Banos Philippines. https://doi.org/10.1093/aob/mcg189

19. Maricel AB (2010) Genetic analysis of agronomic traits, yield components and grain quality in Oryza barthii derivatives. CIAT Annual Report.

20. Matsuo T, Futsuhara Y, Kikuchi F, Yamaguchi H (1997) Science of the Rice plant. Food and Agriculture, Forestry and Fisheries, Genetics: Vol.3.

21. Mohanty S (2009) Why global rice production is plunging. CommodityOnline, available

22. at: http://www.commodityonline.com/news/why-global-rice-production-is-plunging-13800-2-1.html.

23. National Research Council (1996) Lost Crops of Africa: Grains. National Academic Press, Washington, DC, Vol. 1: Pp. 17.

24. Ogunbayo SA, Sie M, Ojo DK, Sanni KA, Akinwale MG, Toulou B, Shittu A, dehen EO, Popoola AR, Daniel IO, and Gregorio GB (2014) Genetic variation and heritability of yield and related traits in promising rice genotypes (Oryza sativa L.). J Plant Breed Crop Sci 6:53-159. doi:10.5897/JPBCS2014.0457

25. Oka HI (1988) Origin of cultivated Rice. Elsevier science Publishers, .Pg. 129. Prajapati, M., Singh, C.M., Suresh, B.G., Lavanya, G.R. Jadhav, P. 2011. Genetic parameters for grain yield and its component characters in rice. Electron J Plant Breed 2(2): 235- 238.

26. Prasad B, Patwari AK, Biswas PS (2001) Genetic Variability and selection criteria in fine grain rice (Oryza sativa). Pak J of Biol Sci 4(10): 1188-1190.

27. Sampath S (1973) Origins of cultivated rice. Indian J of Genet Plant Breed 33:157-161

28. Sarla N, Swamy BPM (2005) Oryza glaberrima: a source for the improvement of Oryza sativa. Curr Sci 89: 955963 Association. Https://www.jstor.org/stable/24110748

29. SAS (2011) SAS procedures guide. 9.4 Edition. SAS Institute Inc., Cary, NC. USA.

30. Scott RA, Milliken GA (1993) A SAS program for analyzing augmented randomized complete block designs. Crop Sci 33: 865-867. https://dx.doi.org/10.2135/cropsci1993.0011183X003300040046x

31. Standard Evaluation System for Rice (SES) (2002) International Rice Research Institute, (IRRI).

32. Los Baños, Philippines. 
33. STAR (2014) STAR Software version 2.0.1. Biometrics and Breeding Informatics. BPGB Division, International Rice Research Institute, Los Banos, Laguna.

34. Sürek H, Korkut KZ, Bilgin O (1998) Correlation and path analysis for yield and yield components in rice in an 8parent diallel set of crosses. Oryza. 35:15-18.

35. Vanniarajan AC, Ramalingam J (2011) Parent Progeny regression analysis in F2 and F3 generations of rice. Electron J of Plant Breed 2: 520-522. http://sites.google.com/site/ejplantbreeding

36. Wolf JB, Wade MJ (2009) What are maternal effects and what are they not? Philos Trans R Soc Lond B Biol Sci 364: 1107-1115. https://doi.org/10.1098/rstb.2008.0238

37. Yadav P, Rangare NR., Anurag PJ Chaurasia AK (2007) Quantitative Analysis of Rice (Oryza sativa L.) in Allahabad Agro-climatic zone J Rice Res 3:16-18.

\section{Tables}

Table 1: List of the parents and the pedigree of $F_{8}$ rice progenies from the IRGC $104084 /$ TGS 25 crosses 


\begin{tabular}{|c|c|c|}
\hline $\mathrm{S} / \mathrm{N}$ & Codes & Pedigree of the genotypes \\
\hline 1 & $\mathrm{P} 1$ & IRGC 104084 \\
\hline 2 & $\mathrm{P} 2$ & TGS 25 \\
\hline 3 & $\mathrm{G} 1$ & ART31-1-1-1-1-1-1-B \\
\hline 4 & $\mathrm{G} 2$ & ART31-1-2-1-1-1-1-B \\
\hline 5 & G3 & ART31-1-3-1-1-1-1-B \\
\hline 6 & $\mathrm{G} 4$ & ART31-38-2-1-1-1-3-B \\
\hline 7 & G5 & ART31-5-2-1-1-1-1-B \\
\hline 8 & G6 & ART31-6-2-1-1-1-1-B \\
\hline 9 & G7 & ART31-7-2-1-1-1-1-B \\
\hline 10 & G8 & ART31-38-2-1-1-1-5-B \\
\hline 11 & G9 & ART31-13-1-1-1-1-1-B \\
\hline 12 & G10 & ART31-17-2-1-1-1-1-B \\
\hline 13 & G11 & ART31-17-3-1-1-1-1-B \\
\hline 14 & G12 & ART31-19-1-1-1-1-1-B \\
\hline 15 & G13 & ART31-19-2-1-1-1-1-B \\
\hline 16 & G14 & ART31-38-2-1-1-1-7-B \\
\hline 17 & G15 & ART31-23-1-1-1-1-1-B \\
\hline 18 & G16 & ART31-23-2-1-1-1-1-B \\
\hline 19 & G17 & ART31-26-3-1-1-1-1-B \\
\hline 20 & G18 & ART31-27-1-1-1-1-1-B \\
\hline 21 & G19 & ART31-27-2-1-1-1-1-B \\
\hline 22 & G20 & ART31-28-3-1-1-1-1-B \\
\hline 23 & G21 & ART31-29-1-1-1-1-1-B \\
\hline 24 & G22 & ART31-29-2-1-1-1-1-B \\
\hline 25 & G23 & ART31-30-1-1-1-1-1-B \\
\hline 26 & G24 & ART31-32-1-1-1-1-1-B \\
\hline 27 & G25 & ART31-36-2-1-1-1-1-B \\
\hline 28 & G26 & ART31-40-2-1-1-1-1-B \\
\hline 29 & G27 & ART31-41-1-1-1-1-1-B \\
\hline
\end{tabular}

Table 2: Descriptive, genetic and variance statistical estimates of 15 phenotypic variables 


\begin{tabular}{|c|c|c|c|c|c|c|c|c|c|}
\hline \multirow[t]{2}{*}{ Variables } & \multirow[t]{2}{*}{ Mean $\pm S E$} & \multirow[t]{2}{*}{ Range } & MS & MS & \multirow[t]{2}{*}{ MS Error } & \multirow[t]{2}{*}{$\mathrm{R}^{2}$} & \multirow{2}{*}{$\begin{array}{l}\mathrm{Hb} \\
(\%)\end{array}$} & \multirow{2}{*}{$\begin{array}{l}\text { GCV } \\
(\%)\end{array}$} & \multirow{2}{*}{$\begin{array}{l}\text { PCV } \\
(\%)\end{array}$} \\
\hline & & & Genotypes & GxE & & & & & \\
\hline Plhtmat & $99.27 \pm 2.37$ & $\begin{array}{l}58.0- \\
231.9\end{array}$ & $1146.17 \star \star$ & $240.33 n s$ & 72.34 & 0.99 & 81.25 & 54.56 & 62.94 \\
\hline Tilno & $12.91 \pm 0.34$ & $\begin{array}{l}6.6- \\
30.9\end{array}$ & $11.72 \mathrm{~ns}$ & $8.99 \mathrm{~ns}$ & 26.23 & 0.91 & 39.80 & 90.78 & 98.09 \\
\hline \multirow[t]{2}{*}{ PAM } & $255.47 \pm 0.99$ & 144.4 & 4012.18ns & $3612.82 \mathrm{~ns}$ & 1119.74 & 0.99 & 50.16 & 70.50 & 80.78 \\
\hline & & 522.5 & & & & & & & \\
\hline Panpl & $16.31 \pm 0.83$ & $\begin{array}{l}5.7- \\
47.2\end{array}$ & $11.52^{\star}$ & $9.55^{\star}$ & 1.44 & 0.99 & 53.43 & 70.61 & 82.14 \\
\hline Panlt & $19.72 \pm 0.82$ & $\begin{array}{l}6.2- \\
28.7\end{array}$ & $4.72^{\star \star}$ & $3.31^{\star \star}$ & 0.21 & 0.99 & 58.27 & 23.96 & 41.13 \\
\hline Fert & $82.41 \pm 1.53$ & $\begin{array}{l}20.1- \\
98.4\end{array}$ & $127.23^{\star \star \star \star}$ & 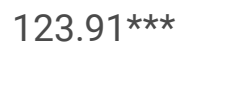 & 1.87 & 0.99 & 50.54 & 54.37 & 60.47 \\
\hline Grnpan & $87.74 \pm 3.12$ & $\begin{array}{l}29.0- \\
171.8\end{array}$ & $4.63 \mathrm{~ns}$ & $1.35 \mathrm{~ns}$ & 398.08 & 0.98 & 3.34 & 5.28 & 8.05 \\
\hline Shatt & $1.10 \pm 0.04$ & $\begin{array}{l}0.7- \\
2.1\end{array}$ & $0.47 \star \star \star$ & $0.10^{\star \star}$ & 0.004 & 0.99 & 82.45 & 43.20 & 52.40 \\
\hline PA & $1.48 \pm 0.02$ & $\begin{array}{l}0.69- \\
2.0\end{array}$ & $0.12^{\star \star}$ & $0.03^{*}$ & 0.004 & 0.99 & 78.71 & 8.52 & 10.82 \\
\hline PE & $1.07 \pm 0.04$ & $\begin{array}{l}0.69 \text { - } \\
1.7\end{array}$ & $0.45^{\star \star \star}$ & $0.08^{\star \star \star}$ & 0.01 & 0.99 & 84.84 & 42.44 & 50.03 \\
\hline Log & $0.75 \pm 0.15$ & $0-4.5$ & $6.27^{\star \star \star}$ & $0.64 \star \star$ & 0.04 & 0.99 & 90.47 & 82.56 & 91.87 \\
\hline Flw & $78.98 \pm 1.35$ & $\begin{array}{l}55- \\
102\end{array}$ & $534.36^{\star \star \star}$ & $19.24 \mathrm{~ns}$ & 3.55 & 0.99 & 96.32 & 67.50 & 70.36 \\
\hline Mat & $110.92 \pm 1.15$ & $\begin{array}{l}86- \\
126\end{array}$ & $395.11^{\star \star}$ & $23.11 \mathrm{~ns}$ & 10.38 & 0.99 & 93.70 & 35.19 & 38.14 \\
\hline GRNWT & $3.17 \pm 0.03$ & $\begin{array}{l}2.5- \\
4.3\end{array}$ & $0.25 \mathrm{~ns}$ & $0.05 \mathrm{~ns}$ & 0.07 & 0.97 & 74.61 & 7.91 & 10.60 \\
\hline YLD & $311.73 \pm 16.12$ & $\begin{array}{l}27- \\
861\end{array}$ & $44116.05^{\star}$ & $10555.18 \mathrm{~ns}$ & 10048.55 & 0.98 & 76.03 & 51.67 & 61.06 \\
\hline
\end{tabular}

† Plhtmat-Plant height at maturity, Tilno- Tiller number, PAM-Panicle per meter square, Panpl- Panicle per plant, Panlt-Panicle length, Fert-Fertility \%, Grnpan-Grain per panicle, Log-lodging Score, Flw-Days to 50\% Flowering, MatDays to $85 \%$ maturity, GRNWT- 1000 grain weight, Shatt-Shattering score, PA-Phenotypic Acceptability, PE-Panicle exsertion, YLD- Yield $g / m 2$

$\dagger *, * \star, * \star *$ - significance at $p \leq 0.05,0.01$ and 0.001

Table 3: Proportions of variances and eigenvector loadings of each of the fifteen traits within principal component axes one to five 


\begin{tabular}{|llllll|}
\hline Variance components & PC1 & PC2 & PC3 & PC4 & PC5 \\
\hline Eigenvalues & 5.028 & 2.820 & 2.202 & 1.036 & 0.928 \\
\hline Proportional variance & 0.335 & 0.188 & 0.147 & 0.069 & 0.062 \\
\hline Cumulative variance (\%) & 33.5 & 52.3 & 67.0 & 73.9 & 80.1 \\
\hline Variables & Eigenvectors & & & \\
\hline PIhtmat & PC1 & PC2 & PC3 & PC4 & PC5 \\
\hline Tilno & 0.107 & -0.158 & -0.544 & -0.287 & 0.093 \\
\hline PAM & 0.341 & 0.215 & 0.053 & 0.091 & -0.073 \\
\hline Panpl & 0.367 & 0.086 & 0.287 & -0.062 & -0.092 \\
\hline Panlt & 0.300 & 0.137 & 0.218 & -0.080 & -0.460 \\
\hline Fert & 0.182 & -0.222 & 0.225 & -0.115 & 0.640 \\
\hline Grnpan & 0.274 & -0.191 & 0.007 & 0.421 & -0.217 \\
\hline Shatt & -0.330 & -0.239 & 0.217 & 0.250 & 0.008 \\
\hline PA & 0.106 & -0.445 & -0.227 & 0.234 & -0.148 \\
\hline PE & -0.171 & 0.256 & -0.381 & 0.031 & -0.173 \\
\hline Log & -0.070 & 0.431 & 0.146 & 0.309 & 0.188 \\
\hline Flw & -0.290 & 0.239 & 0.316 & -0.089 & 0.008 \\
\hline Mat & 0.253 & 0.275 & -0.189 & -0.097 & 0.386 \\
\hline GRNWT & -0.224 & 0.116 & 0.125 & 0.058 \\
\hline YLD & -0.282 & 0.199 & 0.148 & 0.147 \\
\hline
\end{tabular}

† Plhtmat-Plant height at maturity, Tilno- Tiller number, PAM- Panicle per meter square, Panpl- Panicle per plant, Panlt-Panicle length, Fert-Fertility \%, Grnpan-Grain per panicle, Log-lodging Score, Flw-Days to 50\% Flowering, MatDays to 85\% maturity, GRNWT- 1000 grain weight, Shatt- Shattering score, PA-Phenotypic Acceptability, PE-Panicle exsertion, YLD- Yield $\mathrm{g} / \mathrm{m} 2$

Table 4: Mean and variability of the 15 variables within each cluster 


\begin{tabular}{|llllllll|}
\hline & Cluster I & Cluster II & & Cluster III & \multicolumn{3}{c|}{ Cluster IV } \\
\hline Number of genotypes & 1 & 20 & & 2 & & 6 & \\
& Mean & Mean & CV & Mean & CV & Mean & CV \\
\hline Plhtmat & 82.56 & 102.37 & 18.37 & 114.30 & 1.90 & 94.68 & 27.14 \\
\hline Tilno & 15.26 & 13.04 & 10.00 & 15.20 & 2.48 & 10.58 & 11.43 \\
\hline PAM & 259.14 & 265.28 & 12.27 & 321.25 & 2.38 & 197.89 & 15.69 \\
\hline Panpl & 15.68 & 16.93 & 11.63 & 18.65 & 2.65 & 13.83 & 9.89 \\
\hline Panlt & 18.06 & 19.88 & 5.84 & 21.13 & 3.32 & 19.10 & 2.82 \\
\hline Fert & 74.33 & 84.88 & 7.84 & 94.12 & 2.25 & 72.43 & 7.23 \\
\hline Grnpan & 56.61 & 89.29 & 25.06 & 93.75 & 7.62 & 79.91 & 20.29 \\
\hline Shatt & 1.92 & 1.02 & 26.69 & 0.92 & 0.05 & 1.18 & 35.04 \\
\hline PA & 1.95 & 1.46 & 7.20 & 1.39 & 0.01 & 1.48 & 9.45 \\
\hline PE & 1.52 & 0.95 & 26.41 & 0.69 & 0.11 & 1.47 & 27.46 \\
\hline Log & 3.40 & 0.31 & 21.97 & 4.27 & 2.47 & 0.00 & 0.00 \\
\hline Flw & 1358.89 & 3295.06 & 22.92 & 4275.00 & 0.17 & 2267.22 & 38.88 \\
\hline Mat & 53.89 & 78.66 & 10.91 & 58.00 & 0.81 & 97.00 & 3.40 \\
\hline GRNWT & 111.69 & 7.52 & 91.67 & 0.18 & 122.06 & 2.41 \\
\hline YLD & 3.14 & 6.86 & 3.17 & 2.98 & 3.01 & 5.41 \\
\hline & & & & & & & \\
\hline
\end{tabular}

† Plhtmat- Plant height at maturity, Tilno- Tiller number, PAM-Panicle per meter square, Panpl-Panicle per plant, Panlt-Panicle length, Fert-Fertility \%, Grnpan-Grain per panicle, Log-lodging Score, Flw-Days to 50\% Flowering, MatDays to 85\% maturity, GRNWT-1000 grain weight, Shatt-Shattering score, PA-Phenotypic Acceptability, PE-Panicle exsertion, YLD- Yield $g / m 2$

Table 5: Proportional similarities of each of the 27 progenies to the two parents at F6, F7 and F8 


\begin{tabular}{|c|c|c|c|c|c|c|c|c|}
\hline \multirow[b]{2}{*}{ Genotypes } & \multicolumn{4}{|c|}{ Similarities with P1 } & \multicolumn{4}{|c|}{ Similarities with P2 } \\
\hline & F6 & F7 & F8 & Remarks & $\mathrm{F} 6$ & F7 & F8 & Remarks \\
\hline G1 & 43.16 & 48.42 & 46.52 & -ve Quadratic & 73.84 & 83.22 & 64.34 & -ve Quadratic \\
\hline $\mathrm{G} 2$ & 60.38 & 32.38 & 46.97 & +ve Quadratic & 49.39 & 86.46 & 57.69 & -ve Quadratic \\
\hline G3 & 43.06 & 37.89 & 56.31 & +ve Quadratic & 65.41 & 92.51 & 69.56 & -ve Quadratic \\
\hline G4 & 59.28 & 65.59 & 55.53 & -ve Quadratic & 62.88 & 57.62 & 78.82 & +ve Quadratic \\
\hline G5 & 65.29 & 60.47 & 45.92 & -ve Linear & 91.33 & 76.19 & 83.67 & +ve Quadratic \\
\hline G6 & 65.68 & 48.60 & 46.92 & -ve Linear & 72.32 & 64.38 & 87.87 & +ve Quadratic \\
\hline G7 & 60.05 & 38.10 & 49.05 & +ve Quadratic & 78.47 & 91.08 & 76.74 & -ve Quadratic \\
\hline G8 & 59.28 & 50.58 & 43.20 & -ve Linear & 62.88 & 66.18 & 80.63 & +ve Linear \\
\hline G9 & 56.51 & 56.28 & 64.41 & +ve Quadratic & 72.07 & 61.63 & 71.73 & +ve Quadratic \\
\hline G10 & 76.49 & 64.70 & 56.51 & -ve Linear & 61.94 & 64.74 & 81.17 & +ve Linear \\
\hline G11 & 73.55 & 66.79 & 44.40 & -ve Linear & 73.63 & 59.96 & 78.63 & +ve Quadratic \\
\hline G12 & 73.18 & 51.69 & 47.95 & -ve Linear & 54.52 & 81.01 & 74.17 & -ve Quadratic \\
\hline G13 & 65.14 & 81.60 & 51.40 & -ve Quadratic & 76.68 & 52.85 & 60.18 & +ve Quadratic \\
\hline G14 & 59.28 & 69.51 & 55.13 & -ve Quadratic & 62.88 & 58.95 & 54.38 & -ve Linear \\
\hline G15 & 66.51 & 51.43 & 31.07 & -ve Linear & 83.50 & 80.22 & 57.84 & -ve Linear \\
\hline G16 & 67.83 & 42.48 & 46.19 & -ve Quadratic & 82.50 & 91.26 & 74.26 & -ve Quadratic \\
\hline G17 & 83.44 & 51.92 & 42.68 & -ve Linear & 70.96 & 70.96 & 55.44 & -ve Linear \\
\hline G18 & 69.28 & 59.65 & 49.49 & -ve Linear & 73.01 & 71.17 & 84.41 & +ve Quadratic \\
\hline G19 & 70.11 & 50.97 & 48.21 & -ve Linear & 87.34 & 60.42 & 72.27 & +ve Quadratic \\
\hline $\mathrm{G} 20$ & 55.24 & 52.07 & 65.96 & -ve Quadratic & 73.67 & 48.62 & 73.65 & +ve Quadratic \\
\hline $\mathrm{G} 21$ & 53.97 & 43.50 & 54.92 & +ve Quadratic & 77.00 & 73.27 & 69.71 & -ve Linear \\
\hline $\mathrm{G} 22$ & 66.81 & 37.28 & 62.54 & +ve Quadratic & 67.25 & 88.20 & 64.86 & -ve Quadratic \\
\hline G23 & 58.70 & 36.03 & 41.65 & +ve Quadratic & 71.79 & 78.04 & 83.36 & +ve Linear \\
\hline G24 & 78.78 & 50.84 & 40.72 & -ve Linear & 73.81 & 71.52 & 86.98 & +ve Quadratic \\
\hline G25 & 62.54 & 48.73 & 56.33 & +ve Quadratic & 54.87 & 80.63 & 68.73 & -ve Quadratic \\
\hline G26 & 77.12 & 44.75 & 59.59 & +ve Quadratic & 78.73 & 70.39 & 78.77 & +ve Quadratic \\
\hline G27 & 70.21 & 48.28 & 52.44 & +ve Quadratic & 68.51 & 85.99 & 87.76 & +ve Linear \\
\hline Mean & 64.48 & 51.50 & 50.44 & -ve Linear & 71.15 & 72.87 & 73.24 & +ve Linear \\
\hline
\end{tabular}

Table 6: Parent-offspring correlation and regression for some traits in IRGC 104084/TGS 25 cross 


\begin{tabular}{|lllll|}
\hline & \multicolumn{2}{l}{ Correlation $(r)$} & \multicolumn{2}{l|}{ Regression (b) } \\
\hline Traits & $\mathrm{F}_{6}-\mathrm{F}_{7}$ & $\mathrm{~F}_{7}-\mathrm{F}_{8}$ & $\mathrm{~F}_{6}-\mathrm{F}_{7}$ & $\mathrm{~F}_{7}-\mathrm{F}_{8}$ \\
\hline Days to $50 \%$ flowering & $0.096 \mathrm{~ns}$ & $-0.013 \mathrm{~ns}$ & $0.108 \mathrm{~ns}$ & $-0.014 \mathrm{~ns}$ \\
\hline Days to 85\% maturity & $0.111 \mathrm{~ns}$ & $-0.077 \mathrm{~ns}$ & $0.146 \mathrm{~ns}$ & $-0.086 \mathrm{~ns}$ \\
\hline Plant height at maturity & $0.479 \star \star$ & $-0.019 \mathrm{~ns}$ & $0.576 \star \star$ & $-0.021 \mathrm{~ns}$ \\
\hline Tiller numbers & $-0.181 \mathrm{~ns}$ & $-0.093 \mathrm{~ns}$ & $-0.236 \mathrm{~ns}$ & $-0.535 \mathrm{~ns}$ \\
\hline Panicle exsertion & $0.079 \mathrm{~ns}$ & $0.185 \mathrm{~ns}$ & $0.147 \mathrm{~ns}$ & $0.478 \mathrm{~ns}$ \\
\hline Shattering score & $-0.043 \mathrm{~ns}$ & $0.326 \mathrm{~ns}$ & $-0.119 \mathrm{~ns}$ & $0.866 \mathrm{~ns}$ \\
\hline Phenotypic acceptability & $0.009 \mathrm{~ns}$ & $-0.127 \mathrm{~ns}$ & $0.011 \mathrm{~ns}$ & $-1.151 \mathrm{~ns}$ \\
\hline Fertility percentage & $0.033 \mathrm{~ns}$ & $-0.087 \mathrm{~ns}$ & $0.003 \mathrm{~ns}$ & $-0.187 \mathrm{~ns}$ \\
\hline
\end{tabular}

\section{Plates}

Plates 1 and 2 is available in supplementary section.

\section{Figures}

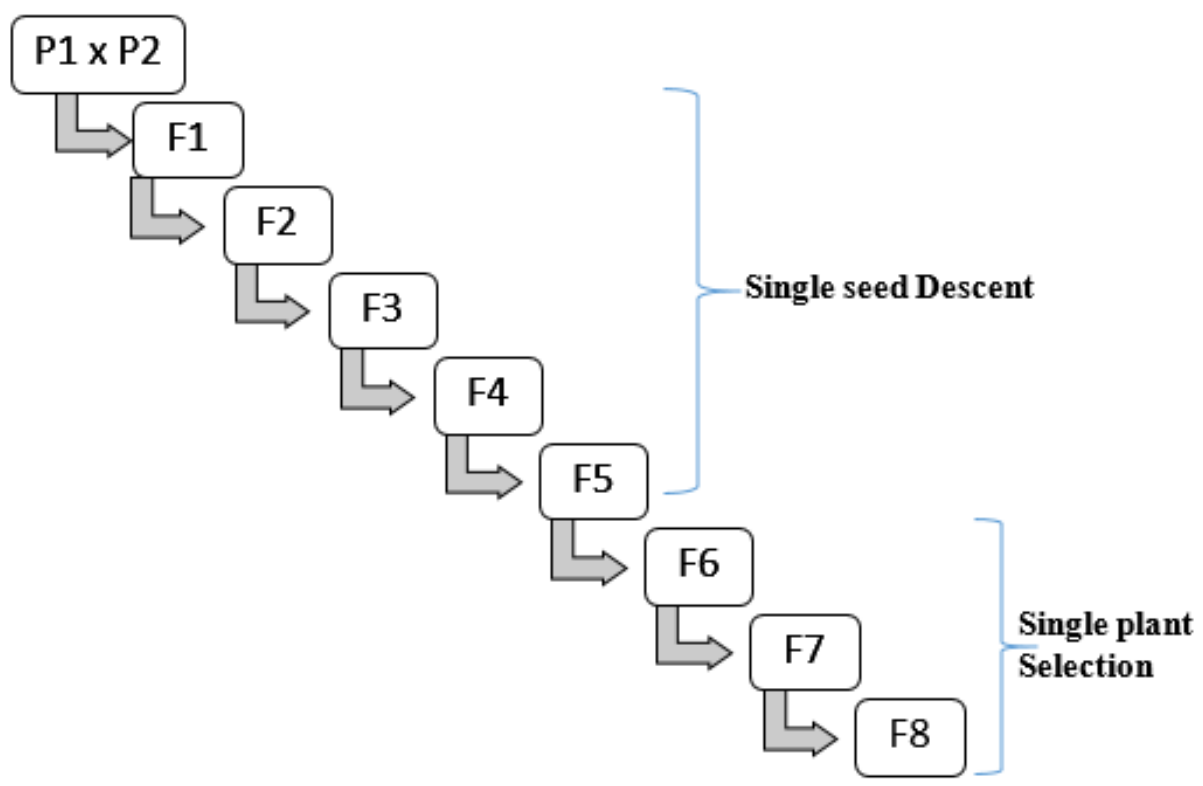

Figure 1

The schematic procedure of the generation of F8 progenies from IRGC 104084/ TGS 25 within three years +P1 - IRGC 104084 (female) and P2 - TGS 25 (male) 


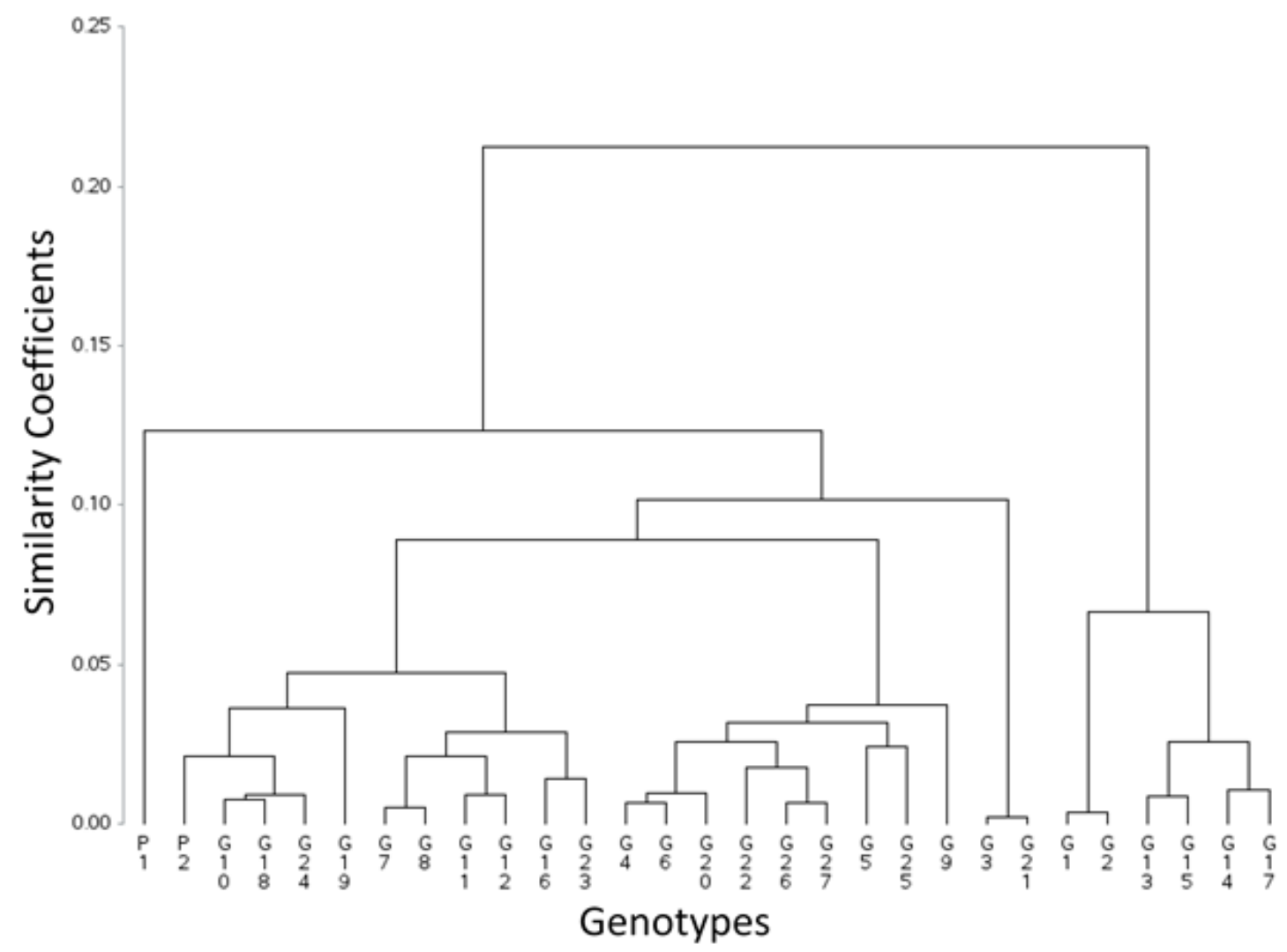

Figure 2

Grouping relationship among the two parents and the $27 \mathrm{~F}_{8}$ genotypes derived from the cross between IRGC 104084/TGS 25 


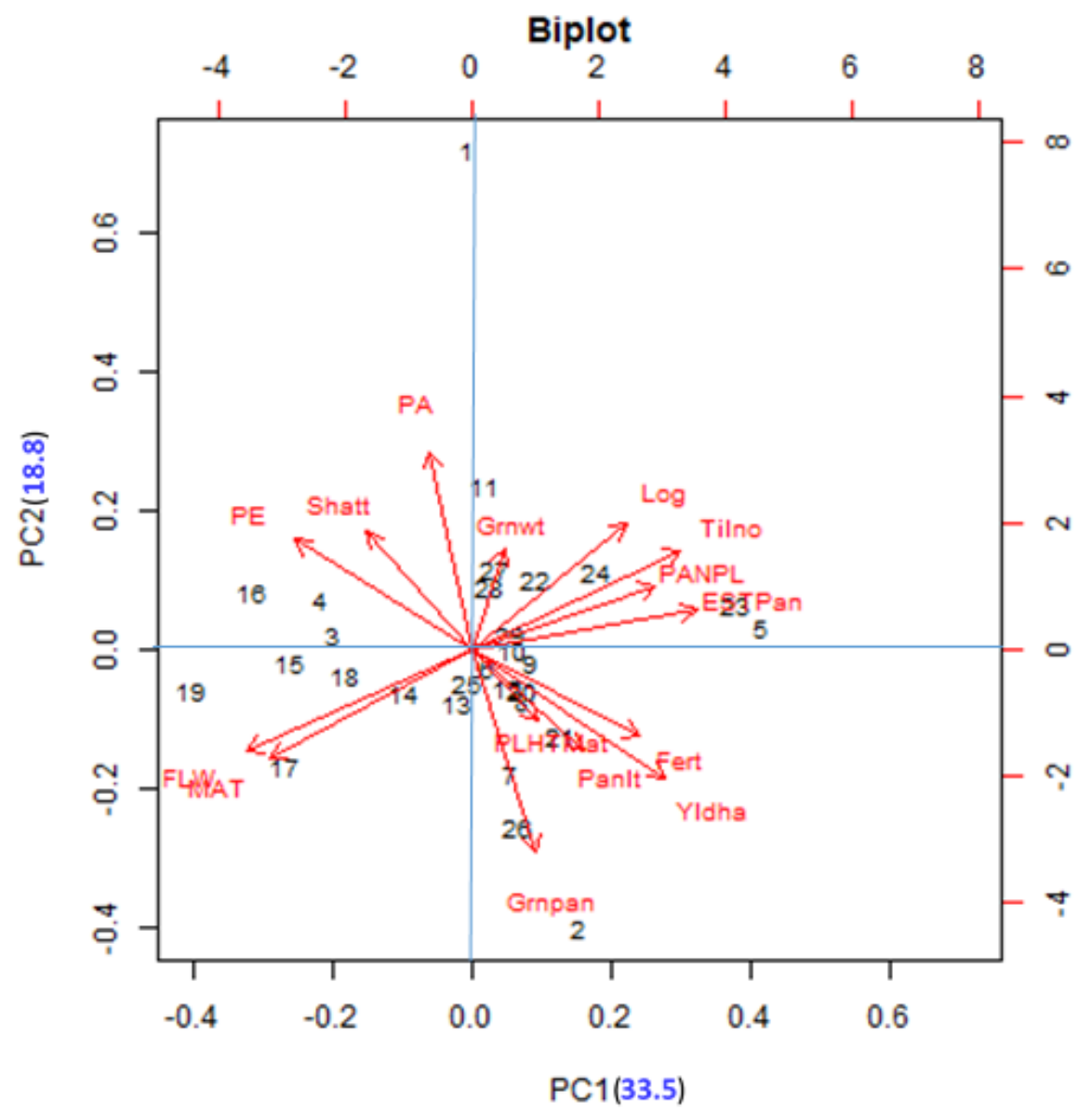

Figure 3

Twenty-nine genotypes by fifteen traits interaction display within the first two principal components

† Plhtmat-Plant height at maturity, Tilno- Tiller number, PAM- Panicle per meter square, Panpl-Panicle per plant, Panlt-Panicle length, Fert-Fertility \%, Grnpan-Grain per panicle, Log-lodging Score, Flw-Days to 50\% Flowering, MatDays to 85\% maturity, GRNWT- 1000 grain weight, Shatt- Shattering score, PA-Phenotypic Acceptability, PE-Panicle exsertion, YLD- Yield $\mathrm{g} / \mathrm{m} 2$

1 - P1, 2 - P2, 3 - G1, 4 - G2, 5 - G3, 6 - G4, 7 - G5, 8 - G6, 9 - G7, 10 - G8, 11 - G9, 12 - G10, 13 - G11, 14 $\mathrm{G} 12,15-\mathrm{G} 13,16-\mathrm{G} 14,17-\mathrm{G} 15,18-\mathrm{G} 16,19-\mathrm{G} 17,20-\mathrm{G} 18,21-\mathrm{G} 19,22-\mathrm{G} 20,23-\mathrm{G} 21,24-\mathrm{G} 22,25-$ G23, 26 - G24, 27 - G25, 28 - G26, 29 - G27

\section{Supplementary Files}

This is a list of supplementary files associated with this preprint. Click to download.

- Plate01.png

- Plate02.png 